\title{
Gelombang Globalisasi ala Korea Selatan
}

Oleh

\section{Annissa Valentina, Ratna Istriyani ${ }^{1}$}

\begin{abstract}
Abstrak
Globalisasi menciptakan kompetisi dan saling ketergantungan di antara negara-negara di dunia. Selama ini, dominasi globalisasi selalu diidentikkan dengan Amerika Serikat. Namun ada fenomena menarik yang sedang populer akhir-akhir ini yang merupakan Korean Wave. Korean Wave merupakan sebuah strategi ekspansi untuk meningkatkan perekonomian Korea Selatan, terutama setelah terjadi krisis di akhir 1990-an. Terdapat aktor di balik Korean Wave di mana pemerintah Korea Selatan yang melakukan konsolidasi dengan perusahaan yang bergerak di berbagai sektor. Konsolidasi, kreativitas, dan kerja keras dari para aktor tersebut mampu meningkatkan perekonomian Korea Selatan secara signifikan. Korean Wave mampu menarik perhatian masyarakat dunia menjadi produk secara luas sebagai budaya alternatif yang mengombinasikan unsur-unsur modernitas (Barat) dengan budaya tradisional (Konghucu).
\end{abstract}

Kata kunci: Korean Wave, globalisasi, aktor.

\begin{abstract}
Globalization had created competition and interdependence among countries in the world. For long time, the dominance of globalization has always been identified with the United States. However there is an interesting phenomenon that's popular lately which is the Korean Wave. In fact, Korean Wave is an expansion strategy to boost South Korea's economy, especially after the crisis in the late 1990s. There are actors behind the Korean Wave that government consolidate with companies engaged in various sectors. Consolidation, creativity, and hard work of the actors were able to improve significantly the South Korean`s economy. Korean Wave is able to attract the attention of the world community into a product widely as an alternative culture that mixes elements of modernity (West) with traditional culture (Confucianism).
\end{abstract}

Keywords: Korean Wave, globalization, and actor.

\footnotetext{
${ }^{1}$ Annissa Valentina adalah mahasiswi pada prodi S2 Sosiologi UGM. Ratna Istriyani adalah mahasiswi S2 Sosiologi UGM angkatan 2013.
} 


\section{A. Pendahuluan}

Globalisasi merupakan proses interdependensi antar negara yang indentik dengan fenomena ekonomi dan teknologi (Hochschild, 2006:41). Globalisasi selama ini selalu dikaitkan dengan proses atau strategi negara-negara Barat dalam melakukan ekspansi produk dan pengaruh, seiring dengan adanya legitimasi lembaga internasional yang mengatur aktivitas secara global seperti IMF, WTO, UNESCO di bawah bendera Perserikatan Bangsa-bangsa (PBB). Dominasi negara-negara Barat begitu melekat dalam alur globalisasi tersebut sehingga menciptakan ketergantungan antara negara dunia ketiga dengan negara-negara maju tersebut. Globalisasi juga membawa pengaruh melalui budaya (globalized culture).

Waters mendefinisikan budaya global berkaitan dengan aliran ide yang berkelanjutan, informasi, komitmen, nilai dan selera termediasi yang memengaruhi pergerakan individual, tanda atau simbol, dan simulasi-simulasi elektronik. Ketika budaya sudah termediasi dan ditransformasikan dalam sebuah proses, globalisasi adalah suatu proses dialektis yaitu penyeragaman atau penganekaragaman budaya. Penyeragaman identik dengan imperialisme dan kekuatan asimetris. Imperialisme mengarah pada proses Amerikanisasi yang menimbulkan konsumsi terhadap budaya dan produk-produk material lainnya. Kekuatan asimetris yaitu dominasi Barat dalam mengembangkan konsep globalisasi (dalam Eun dan Jiwon, 2007:124). Media menjadi senjata yang efektif dan efisien dalam proses globalisasi terutama budaya. Media menjadi agen yang menyebarkan budaya secara masif. Sementara itu penganekaragaman budaya berkaitan dengan proses adaptasi budaya baru yang masuk terhadap budaya tradisional yang kemudian semakin memperkaya budaya dalam suatu negara, dengan kata lain disebut dengan proses akulturasi.

Fenomena baru muncul dalam era globalisasi yang selama ini didominasi oleh negara-negara Barat seperti Amerikanisasi. Korean Wave muncul dan menjadi fenomena globalisasi versi Asia yang booming dalam dekade terakhir ini, kemudian secara siginifikan memengaruhi berbagai negara di beberapa belahan benua termasuk Indonesia. Korean Wave atau Hallyu sepertinya bukanlah istilah yang asing bagi masyarakat kita, bahkan badai Korea itu tengah melanda sebagian remaja Indonesia. Korean Wave atau Hallyu memang tengah booming untuk dekade ini di Indonesia. Suguhan produk berbau Korea Selatan perlahan mengubah selera dan paradigma remaja sekarang tentang sebuah tren yang dulu sempat dibawa oleh budaya Western. Salah satu faktor penyebab masuknya budaya Korea Selatan ke Indonesia yaitu adanya arus globalisasi yang terjadi, dan Indonesia yang menjadi sasaran empuk ekpansi pasar negaranegara kapitalis terutama Korea Selatan.

Budaya tersebut sudah masuk ke berbagai lini kehidupan masyarakat kita. Pengaruhnya cukup signifikan, yaitu mulai dari fashion, lifestyle, musik, film dan drama. Hampir setiap hari media cetak maupun elektronik menyajikan berbagai hiburan ala Korea Selatan secara masif. Hallyu ternyata bukan hanya melanda masyarakat secara umum tetapi juga sempat mewarnai industri hiburan tanah air sehingga kehilangan kekhasannya karena berkiblat pada aliran Hallyu. Berbagai produk hiburan yang menduplikasi sajian ala Korea mulai menjamur dan mencapai titik klimaks pada kisaran beberapa 
Jurnal Pemikiran Sosiologi Volume 2 No. 2, 2013

Gelombang Globalisasi ala Korea Selatan

Annissa Valentina, Ratna Istriyani

tahun terakhir ini. Boy Band dan Girl Band ala Korea Selatan bermunculan, bahkan sinetron, film televisi, pertunjukan dengan aliran cerita ala Korea Selatan merebak dan disiarkan di beberapa stasiun televisi tanah air.

Merebaknya Korean Wave merupakan dampak dari adanya arus globalisasi yang melanda Indonesia. Akses yang cepat pun semakin mempercepat persebaran Korean Wave. Media dalam negeri turut mempercepat persebaran budaya ala Korea kepada masyarakat. Pengemasan produk budaya Korea Selatan secara simultan dan kompleks memengaruhi selera massa secara keseluruhan. Misalnya pertunjukan serial dramanya secara kompleks memengaruhi selera konsumen mulai dari lagu sountrack (musik), bahasa, fashion, makanan, teknologi, setting tempat sampai dengan romansa yang disajikan dalam drama tersebut dan semua itu kemudian mengarahkan selera konsumen. Implikasinya kemudian menjamurnya produk fashion, restoran, supermarket, dan hiburan ala Korea di Indonesia.

Pengaruh lain dari arus Korea di Indonesia tampak pada produk smartphone Samsung yang tiba-tiba merajai industri teknologi Indonesia dan mulai menggeser produk Eropa lainnya. Bisa jadi itu bukan sekedar hal yang kebetulan melainkan sebuah politik ekonomi Korea Selatan melalui produk budaya. Kenyataannya produk-produk teknologi dan produk material lainnya mengalami peningkatan penjualan yang signifikan seiring dengan Korean Wave yang melanda berbagai negara di Asia Timur, Asia Tenggara, Asia Selatan, sebagian negara Eropa dan Amerika. Mungkinkah Korean Wave memang diciptakan dan menjadi strategi pasar yang dilakukan oleh Korea Selatan? Seperti yang disampaikan oleh Wallerstein bahwa tren diferensiasi budaya atau kompleksitas budaya berkaitan dengan sistem kerja ekonomi kapitalis dan budaya sebagai bagian dari ekploitasi (dalam Eun dan Jiwon, 2007: 124).

Berdasarkan berbagai masalah tersebut, tulisan ini ditujukan untuk memberikan pencerahan bagaimana globalisasi yang dibanggakan banyak orang dengan membawa masuk Korean Wave ini ternyata membawa dampak yang cukup besar dalam kehidupan masyarakat Indonesia. Selain itu melihat Korean Wave bukan hanya sebagai fenomena global yang merasuki masyarakat dunia termasuk Indonesia melainkan bagaiman Korean Wave itu muncul dan ada apa dibalik arus Korea yang booming tersebut. Selanjutnya aktor-aktor yang berperan serta struktur yang mendukung munculnya Korean Wave yang mendunia tersebut. Berdasarkan pemaparan latar belakang di atas maka rumusan masalah yang hendak dibahas dalam analisis ini yaitu fakta apakah yang terdapat di balik boomingnya Korean Wave dan siapa saja aktor yang berperan dalam menyebarluaskan Korean Wave hingga melintasi berbagai negara di berbegai belahan dunia?

\section{B. Korean Wave (Hallyu)}

Pada awal pembahasan ini, perlu dipaparkan mengenai fenomena Korean Wave atau Gelombang Korea. Korean Wave atau Hallyu merupakan produk budaya yang muncul pasca keemasan produk budaya Jepang pada era akhir 1970 sampai pertengahan 1990-an (animasi, komik, game, musik, dan drama TV) atau produk film action Hong Kong. Hallyu lebih meluas dibandingkan dengan 
kedua produk budaya tersebut karena sifatnya yang dianggap lebih terbuka dan menghindari segala bentuk diskriminasi. Selain itu Hallyu menjadi sebuah produk budaya alternatif yang mencoba mencampurkan unsur budaya Barat dan Timur namun tidak meninggalkan kekhasan budaya lokalnya (Eun dan Jiwon, 2007).

Korean Wave (Hallyu) merupakan budaya yang berasal dari Korea Selatan dan istilah yang diberikan persebaran budaya pop Korea Selatan secara global di seluruh dunia tanpa terkecuali Indonesia, yang secara singkat mengacu pada globalisasi budaya Korea. Istilah tersebut mulanya diperkenalkan oleh media China untuk menggambarkan booming hiburan Korea di China pada akhir tahun 1990-an. Korea Tourism Organization (2004) mendefinisikan Hallyu sebagai fenomena budaya terkini di Korea Selatan yang mulai merambah Cina, Jepang, Taiwan, Vietnam, Singapura, Thailand, Indonesia dan negara-negara lain di Asia Tenggara bahkan sudah sampai ke beberapa negara belahan Eropa dan Amerika (Meksiko, California, New York, dan Pantai Antlantik Amerika Serikat). Korea Selatan bukan hanya berekspansi melalui produk musik, film, drama, dan pesona para bintangnya melainkan juga melebarkan popularitasnya melalui makanan dan bahasanya yang juga merupakan bagian dari budaya warga Korea Selatan.

Sebuah blog milik Alien Wardani juga mengungkapkan bahwa Korean Wave mengacu pada penyebaran budaya Korea Selatan di seluruh dunia atau kecintaan terhadap ekspor budaya Korea Selatan. Korean Wave merujuk pada peningkatan secara signifikan popularitas budaya Korea Selatan di seluruh dunia sejak abad 21, terutama di kalangan
Generasi Net. Hal ini juga disebut sebagai Hallyu dari pengucapan Korea. Hallyu atau Korean Wave pada hakikatnya merupakan fenomena gelombang budaya Korea Selatan yang disebarkan melalui Korean Pop Culture ke seluruh penjuru dunia lewat media massa, dan yang terbesar lewat jaringan internet serta televisi. Istilah ini diciptakan di China pada pertengahan 1999 oleh jurnalis Beijing yang terkejut dengan popularitas budaya Korea Selatan di Cina yang berkembang pesat. Dari sebuah budaya lokal menjadi sebuah brand image, itulah Korean Wave. Sebuah kampanye yang sangat menarik melalui berbagai macam cara untuk memperkenalkan Korea Selatan.

Sulit dipungkiri bahwa ternyata cukup banyak orang yang tertarik menonton drama Korea, mendengar musik K-pop (Korean pop), makanan khas korea, pakaian khas Korea, belajar berbahasa Korea (hangul) bahkan brand-brand dari Korea Selatan mulai merajalela di tengah krisis global ini. Korea Selatan adalah salah satu dari sepuluh negara teratas dunia sebagai eksportir budaya dan Korean Wave dimulai dengan mengekspor drama TV Korea seperti Autumn Fairy Tale, Winter Sonata, Dae Jang Geum (Jewel In The Palace), dan Princess Hours di seluruh Asia Timur dan Asia Tenggara.

Munculnya Korean Wave ini masih tergolong baru karena muncul di akhir 1990-an. Jika orang-orang yang lahir pada tahun 1970-an atau 1980-an ditanya mengenai serial drama, film atau musik dari negara Asia mana yang populer di Indonesia pada era generasinya, mungkin mereka akan menjawab Jepang, Cina, dan Hongkong, tanpa menyebut Korea di dalamnya. Ilustrasi ini disimpulkan berdasarkan hasil studi yang dilakukan oleh Kawakimi dan Fisher (1994) mengenai industri musik Asia yang 
Jurnal Pemikiran Sosiologi Volume 2 No. 2, 2013

Gelombang Globalisasi ala Korea Selatan

Annissa Valentina, Ratna Istriyani

menempatkan Jepang, Cina, dan Hongkong sebagai negara-negara yang musiknya remarkable.

Persebaran dan peningkatan ekspor budaya Korea bukan hanya menjadi kesuksesan perusahaan hiburan Korea Selatan melainkan juga menjadi kesuksesan pemerintah dalam membangun ekonominya melalui industri budaya, bahkan produk budaya ini menjadi sumber kebanggaan pemerintah korea (Eun dan Jiwoon, 2007: 119). Industri tersebut telah memberikan peningkatan perekonomian secara meningkat karena turut meningkatkan angka pengunjung atau turis di sektor pariwisata. Departemen Kebudayaan dan Pariwisata mencatat pertumbuhan ekonomi Korea mencapai rata-rata 5,5\% per tahun dari kurun 19932003 di sektor hiburan. Pada tahun 2005, ekpor budaya Korea (film, musik, permainan, dan drama TV) mencapai US \$ 1 miliar (meningkat 31\% dibandingkan tahun 2004). Booming Hallyu juga meningkatkan jumlah wisata asing ke Korea Selatan, khususnya dari Jepang dan China yang merupakan negara yang paling awal terkena Korean Fever.

\section{Korean Wave di Indonesia}

Selain mewabah di beberapa negara lain, Korean Wave juga melanda Indonesia pada tahun 2002, bertepatan dengan pemutaran drama Korea yang berjudul Autumn in My Heart atau yang lebih kita kenal dengan Endless Love di salah satu televisi swasta nasional. Serial drama tersebut ternyata mampu memikat penonton karena ceritanya yang kental dengan nuansa percintaan dan keluarga. Endless Love mampu menarik emosi penikmatnya di Indonesia. Keberhasilan drama tersebut membuka pintu bagi drama Korea Selatan lainnya untuk mewarnai hiburan di Indonesia.

Kelebihan drama dan film Korea Selatan yang mampu memikat remaja Indonesia antara lain aktor dan aktrisnya memiliki penampilan memikat. Aktoraktor muda memang menjadi agen utama dalam persebaran Korean Wave karena segmentasi utama produk budaya Korea Selatan adalah remaja atau dewasa. Bintang muda menjadi sentral dalam menyampaikan nilai klasik (cinta, persahabatan, dan keluarga) dalam produk budaya Korea Selatan. Tema klasik menjadi poin utama dalam produk karena lebih mampu memikat emosi konsumen. Kendati kental dengan nuansa tema klasik, produk budaya Korea Selatan tidak meninggalkan kesan modern dan ciri khas budayanya.

Berkembangnya budaya pop Korea Selatan (Hallyu) di negara-negara Asia Timur dan beberapa negara Asia Tenggara termasuk Indonesia menunjukkan adanya transformasi budaya asing ke negara lain. Berkembangnya budaya pop Korea di Indonesia dibuktikan dengan munculnya "Asian Fans Club" (AFC) yaitu blog Indonesia yang berisi tentang berita dunia hiburan Korea Selatan. AFC didirikan pada 1 Agustus 2009 oleh seorang remaja perempuan bernama Santi Ela Sari. Berdasarkan data statistik dari situs Pageran Alexa, AFC adalah situs 'Korean Intertainment' terbesar di Indonesia. Jumlah pengunjung AFC sampai dengan Juni 2011 adalah 42.811.744 orang. Hal ini berarti Asian Fans Club dikunjungi oleh rata-rata 58.646 orang setiap hari. Jumlah posting dari Juni 2009 sampai Juni 2011 mencapai 16.974. Dalam kurun waktu tersebut selalu terjadi peningkatan posting di setiap bulannya. 
Data di atas menunjukkan bahwa budaya pop Korea Selatan di Indonesia berkembang cukup pesat dalam kurun waktu dua tahun. Dengan demikian, berkembangnya budaya pop Korea (Korean Wave) di Indonesia merupakan perwujudan globalisasi dalam dimensi komunikasi dan budaya. Globalisasi dalam dimensi ini terjadi karena adanya proses mengkreasikan, menggandakan, menekankan, dan mengintensifikasi pertukaran serta kebergantungan informasi dalam dunia hiburan, dalam hal ini adalah dunia hiburan Korea Selatan.

Korean Wave yang mewabah di Indonesia telah berpengaruh pula pada pola konsumsi masyarakat, sebab produk-produk Korea Selatan menjadi incaran banyak kalangan. Tren mode ala Korea menjadi menjamur di lingkungan masyarakat, terutama kalangan muda. Berbagai distro dan resto bernuansa Korea bermunculan di Indonesia. Korean Wave bahkan sempat menyeragamkan industri hiburan Indonesia yang bernuansa Korea. Hal itu ditandai dengan bermunculannya Girl dan Boy Band berkonsep Korea, Film Televisi yang mengadopsi cerita-cerita drama serta film Korea, bahkan beberapa show di TV juga mengadopsi show yang disiarkan di Korea.

\section{Korean Wave: Strategi Ekspansi Pasar Korea} Selatan: Aktor-aktor dan Fakta di Balik Korean Wave

Seperti yang dipaparkan di atas bahwa globalisasi mengarah pada hubungan interdependensi dan homogenisasi dalam skala makro, melibatkan hubungan antar negara yang semakin intens. Globalisasi adalah sebuah sistem yang ditandai dengan lalu lintas, pertukaran, dan kegiatan ekonomi di setiap saat dan sudut tempat. Sistem itulah yang kemudian mendorong aktivitas kapitalis semakin leluasa karena globalisasi menyediakan pintu untuk memperluas kegiatan ekspansi (Subangun, 1995: 211). Globalisasi dan kapitalisme dalam konteks ini adalah fenomena Korean Wave yang layak dijelaskan secara Sosiologis. Fenomena tersebut secara secara garis besar dapat dianalisis dengan teori globalisasi yang dikemukakan oleh Kellner yang kental dengan perspektif neo-marxis. Faktanya globalisasi dan kapitalisme adalah sebuah pola yang berlangsung dalam konteks global yang memperlihatkan adanya hubungan dialektis antara teknologi, ekonomi, politik, dan kebudayaan. Jaringan global atau transnational network menjadi jalur pertukaran antar aktor baik itu Transnational Coorporate (TNC/Multinational Coorporate (MNC) dan negara dalam berbagai kepentingan dan bidang, termasuk kontestasi untuk menunjukkan eksistensi negara. Hal itu seperti yang diungkapkan Kellner berikut. Globalisasi melibatkan pasar kapitalis dan serangkaian relasi sosial dan aliran komoditas, modal, teknologi, gagasan, bentuk kebudayaan, dan orang-orang di seluruh batas nasional melalui masyarakat jaringan global. Transmutasi teknologi dan modal bekerja sama menciptakan dunia global dan terkait satu sama lain. Revolusi teknologi yang terkomputerisasi, transportasi, dan pertukaran adalah prasyarat ekonomi global, bersama dengan perluasan sistem pasar kapitalis dunia yang semakin menyerap wilayah dunia dan ranah produksi, pertukaran, dan konsumsi ke dalam orbitnya. (dalam George Ritzer dan Douglas J. Goodman, 2010: 636).

Merujuk pada fenomena tentang Korea Selatan, dalam hal ini ia hadir sebagai negara kapitalis 
Jurnal Pemikiran Sosiologi Volume 2 No. 2, 2013

Gelombang Globalisasi ala Korea Selatan

Annissa Valentina, Ratna Istriyani

karena dipengaruhi oleh dominasi dan relasi dengan Amerika Serikat. Secara politis Korea Selatan memang tidak bisa dipisahkan dengan negara adidaya yang menjadi leader globalisasi tersebut karena riwayat kolonialisasi. Oleh karena itu banyak taktik atau strategi yang sebagian diadopsinya, namun pada akhirnya Korea Selatan memiliki ciri khasnya sendiri. Bahkan Korea Selatan menjadikannya sebagai kiblat atas semangat modernitas dan berusaha menjadi negara maju baru, khususnya di Asia. Oleh karena itu bisa dikatakan bahwa Korea Selatan turut mengikuti semangat globalisasi Amerika Serikat. Meminjam asumsi Kellner di atas bahwa globalisasi melibatkan sebuah proses dialektika teknologi, ekonomi, politik, dan kebudayaan; maka proses menggobalnya Korean Wave juga tidak bisa dilepaskan dari dialetika tersebut. Namun, Korea Selatan memiliki kekhasannya sendiri untuk melebarkan sayap dan pengaruhnya melalui arena globalisasi.

Pada awalnya Korea Selatan adalah negara miskin yang terdominasi oleh negara tetangganya yaitu Jepang dan Cina yang secara ekonomi dan politik lebih mapan. Korea Selatan mengalami kondisi ekonomi dan politik yang memprihatinkan terutama setelah terpisah dengan negara tetangga yaitu Korea Utara yang berideologi komunis. Korea Selatan tidak punya sumber ekonomi yang mapan setelah terjadi perpisahan itu karena kegiatan pertanian dan industri dipusatkan di wilayah Korea Utara pada saat keduanya masih dalam satu kesatuan. Oleh karena itu Korea Selatan kemudian membangun kondisi ekonomi dan politik terutama setelah datangnya Amerika Serikat sebagai trendsetter yang sedikit banyak turut memengaruhi perkembangannya. Pada sektor ekonomi, Korea
Selatan berusaha menjadi negara yang berorientasi ekpor dan mengurangi ketergantungan internasional dengan meningkatkan produktivitas dibandingkan konsumsi. Program itu dicanangkan pada awal tahun 1960-an. Pada bidang politik melalui slogan win international competition. Oleh karena itu, Korea Selatan mencoba membangun dan menata kembali sistem politik dan birokrasinya untuk menunjang upaya pembangunan, terutama menekankan pada peran pemerintah yang lebih cair serta penuh komitmen. Hal itu sungguh dimaknai karena terbukanya jaringan global berarti memberi kesempatan bagi kontestasi, dan Korea Selatan tidak ingin terus menjadi obyek namun subjek dalam arus globalisasi.

Perekonomian Korea Selatan tumbuh dengan bangunan kapitalisme yang berbeda dengan Barat bahkan dengan Jepang yang sudah mendahuluinya dalam hal kemajuan industri. Bermodalkan masyarakat kosmopolit dan penataan birokrasi serta politik, Korea Selatan menjadi negara yang disebut sebagai negara ajaib menjelang awal tahun 1990-an. Hal itu dapat dilihat dari nilai ekpornya yang mencapai \$55 Milyar, berbeda jauh dibandingkan dengan tahun 1960-an yang hanya $\$ 55$ juta.

Pada arus globalisasi dan proses dialektis seperti diungkapkan Kellner tersebut tentu tidak dapat dipisahkan dari aktor-aktor yang menggerakkan. Pada kasus proses penciptaan Korean Wave atau globalisasi ala Korea Selatan melibatkan aktor penting dan itu menjadi ciri khasnya yaitu keterlibatan negara dalam mengendalikan arah globalisasi. Dalam hal ini negara atau pemerintah tidak hanya menjadi lembaga superordinat yang mengatur kegiatan ekonomi secara dominan namun 
Jurnal Pemikiran Sosiologi Volume 2 No. 2, 2013

Gelombang Globalisasi ala Korea Selatan

Annissa Valentina, Ratna Istriyani

negara hadir, berkonsoliasi/berkolaborasi dan memberdayakan perusahaan swasta untuk melebarkan sayapnya sampai lingkup internasional atau kontestasi global. Perusahaan yang terlibat dalam hubungan tersebut adalah industri produk budaya, industri produk komersial, dan dibantu oleh media. Pemerintah dan perusahaan swasta secara sadar membangun negaranya agar menjadi negara yang punya eksistensi dalam ruang global. Konsistensi mereka dalam membangun hubungan kerjasama dan kekeluargaan tersebut telah memunculkan ide, kreasi, dan inovasi produk yang kemudian berpengaruh pada tingkat pendapatan negaranya. Salah satu contoh sukses hubungan konsolidasi tersebut adalah perusahaan Samsung yang berhasil menguasai 30\% pasar komputer dunia di tahun 1990-an (Subangun, 1995:125).

Globalisasi telah mempertemukan negara-negara di dunia dalam satu pasar global yang bebas, dan di antara negara-negara tersebut memiliki sistem serta budaya yang berbeda. Hal itu kemudian dibaca oleh kapitalisme sebagai sebuah peluang. Watak kapitalisme pun berubah, di mana faktor kunci tidak lagi dalam aktivitas produksi tetapi dalam sistem kekuasaan dan kebudayaan (Subangun, 1995: 212). Sebagai negara kapitalis Korea Selatan memahami itu dan mulai berorientasi dan berinovasi dengan hal itu. Korea Selatan melakukan hal yang sama dengan dilakukan Amerika Serikat dan Jepang yang sukses dengan produksi budaya dan kekuasaannya dalam industri global melalui jaringan internasional yang kini telah terbuka. Jika Amerika kental dengan Amerikanisasinya dan Jepang dengan Japanisasinya maka Korea Selatan punya brand image bernama Korean Wave atau Hally, dan fenomena tersebut yang menjadi proses penyebaran budaya melalui industri budaya. Era ini telah menjadi masanya Korean Wave menjadi fenomena global yang mulai mencapai titik sukses dalam menggeser keemasan Amerika Serikat dan Jepang di pasar global.

Korean Wave merupakan arus yang sengaja dibuat sebagai proses industri, bahkan adanya konsolidasi yang melibatkan pemerintah Korea Selatan dan swasta seperti yang dijelaskan pada pemaparan sebelumnya. Mulanya usaha itu dilakukan sebagai upaya untuk keluar dari krisis ekonomi yang dialami oleh sebagian negara Asia di akhir tahun 1990-an. Korean Wave tersebut disebut juga sebagai fenomena kapitalisme Asia dan proses kapitalisme global, dan menggunakan teknologi media sebagai alat ekspansi yang memfasilitasi sirkulasi secara simultan dalam proses penyebaran produk budayanya. Oleh karena itu Korean Wave memang output atau strategi dari kegiatan industri budaya yang sekaligus menggunakan teknologi media sekaligus mempopulerkan produk teknologi Korea Selatan, hal ini kemudian proses dialektika teknologi dan penyebaran.

Korea Selatan menyadari bahwa globalisasi (menyatunya pasar dengan sistem kapitalis) sarat dengan proyek modernitas dan tidak hanya menempatkan produksi dalam segi fisik melainkan juga produksi makna. Produsen mengendalikan konsumen dalam mengkonsumsi dan memaknai produk tertentu, dan media menjadi wahana untuk merepresentasikan itu. Dalam istilah Jean Baudrillard, produk atau barang konsumsi bukan sekedar komiditas yang mengandung nilai guna melainkan tanda atau "sign" (message atau image) yang mampu menarik minat konsumen tanpa mempedulikan nilai guna. Dalam kapitalisme global, produsen menjadi aktor penting yang memproduksi 
Jurnal Pemikiran Sosiologi Volume 2 No. 2, 2013

Gelombang Globalisasi ala Korea Selatan

Annissa Valentina, Ratna Istriyani

makna sehingga mampu menyetir konsumennya (Baudrillard, 1998: 7). Itu pula yang dilakukan Korea Selatan sebagai produsen dan aktor kapitalis, yaitu menggencarkan industri budayanya melalui berbagai media, seperti yang pernah dilakukan oleh Amerika dan Jepang.

Industri budaya berkaitan dengan segala macam aktivitas pengembangan, produksi, distribusi, dan konsumsi. Produk budaya itu sendiri berkaitan dengan berbagai benda atau pelayanan yang tampak maupun tidak tampak, atau kombinasi dari keduanya yang menghasilkan nilai tambah menggunakan elemen budaya (muatan budaya dan muatan budaya digital). Produk budaya meliputi pertunjukan, seni rupa dan literatur, reproduksi, buku, majalah jurnal, koran, film, radio, televisi, dan musik (Eun dan Jiwon, 2007: 120-121).

Korean Wave berhasil memberikan pengaruh besar dalam perekonomian Korea Selatan karena tidak terlepas dari pembagian peran antara aktor-aktor di balik itu yang berjalan secara konsisten, antara lain sebagai berikut;

\section{1) Pemerintah:}

Pemerintah berperan dalam membuat kebijakan yang mendorong berkembangnya industri produk budaya dan komersil lainnya di Korea Selatan. Pemerintah juga membantu dalam proses promosi dengan memanfaatkan hubungan diplomasinya dengan negara-negara lain.

\section{2) Perusahaan dan Media:}

Media menjadi agen utama yang secara simultan menyebarluaskan Korean Wave melalui penayangan produk budaya dan produk komersial lainnya seperti drama, film, iklan, musik, dan sebagainya.
Dalam hal ini media bekerja sama dengan industri budaya dan industri komersial untuk menetukan strategi dalam mempromosikan produk melalui produksi makna. Konsumen diarahkan dan seolah dihipnotis sehingga banyak yang terlena, tertarik, dan terus-menerus mengkonsumsi produk berbau Korea Selatan.

Menurut Adorno dan Horkheimer media sebagai industri budaya bukan hanya beperan dalam memuluskan masifikasi produk budaya, media juga memanipulasi kesadaran dan pikiran manusia yang akhirkan mengabaikan nilai tukar dan nilai guna. Dengan kata lain media menciptakan kesadaran palsu, konsumen sebenarnya butuh namun menjadi seolah-olah butuh karena produksi makna yang ditonjolkan media. Dari proses itu masyarakat akan tertarik untuk mengkonsumsi produk-produk baru. Contoh dalam industri budaya Korea Selatan adalah film, drama, musik, dan fashion yang semuanya disebarkan dalam gerak Korean Wave.

Kerja sama antar aktor tersebut dalam mewacanakan dan menyebarluaskan Korean Wave telah mendongkrak perekonomian Korea Selatan melalui optimalisasi produk kebudayaan dan teknologi, sehingga Korean Wave diiringi dengan meningkatnya produk-produk dan pendapatan Korea Selatan (Cho, 2005). Peningkatan tersebut terlihat dari beberapa bidang antara lain sebagai berikut;

1) Industri hiburan:

Industri hiburan menjadi ikon dari keberhasilan Korean Wave karena bukan hanya menjadi media untuk menyebarkan namun juga menjadi sektor yang mendapatkan banyak keuntungan. Pada tahun 2000 saja tercatat $56 \%$ dari produk film telah 
berhasil diekspor ke beberapa negara. Produk budaya yang mengalami peningkatan bukan hanya film saja namun juga drama, musik games, advertising, broadcasting, film dan pertunjukkan (Eun dan Jiwon, 2007: 122). Produk budaya Korea Selatan tersebut mengalami peningkatan yang luar biasa pada tahun 2011 yaitu sebesar USD 73,3 Milyar (meningkat 13,2\% dari tahun sebelumnya), sedangkan angka ekspornya mencapai USD 4,3 Milyar atau meningkat $34 \%$ dibandingkan tahun sebelumnya. Salah satu pertunjukan musik/konser yang laris dan memberikan keuntungan besar dalam industri hiburan Korea Selatan adalah pertunjukan musik bintang hiburan Korea Selatan yaitu Rain. Pada tahun 2006 tiket pertunjukan salah bintang hiburan tersebut mencapai 130.000 di beberapa negara di Asia Timur (Jepang, Cina, dan Hongkong). Di tahun yang sama pertunjukan Rain mampu menjual tiket 10.000 di New York (Eun dan Jiwon, 2007: 131). Itu hanya produk dari salah satu jenis produk budaya dari salah satu bintang hiburan. Masih banyak produk lain dan banyaknya bintang hiburan Korea Selatan yang mendatangkan keuntungan besar bagi Korea Selatan.

2) Industri fashion:

Meluasnya Korean Wave diikuti dengan meningkatkan konsumsi hasil industri fashion. Berbagai produk fashion laris di pasaran nasional maupun global. Industri fashion dalam hal ini meliputi dua macam yaitu industri konveksi dan industri kecantikan

a. Industri konveksi

Citra trendy dalam produk budaya Korea Selatan seperti drama, film, dan musiknya mampu menarik perhatian banyak orang untuk turut menjadi konsumen produk konveksinya. Produk mode ala Korea menjamur di pasaran dan tengah menjadi tren di kalangan muda.

b. Industri kecantikan/perawatan tubuh. Korea Selatan mampu mendoktrin banyak orang bahwa kecantikan dan ketampanan bisa dibuat, dan setiap orang seharusnya peduli dengan penampilan. Hal itu yang digambarkan dari para bintang hiburan Korea Selatan yang selalu tampil sempurna, bersih, dan bersinar. Sejauh ini bukan hanya produk kecantikan saja yang booming namun operasi plastik juga tengah menjadi tren. Korea Selatan bahkan menjadi negara yang secara terbuka mendeklarasikan diri sebagai tujuan bagi siapa saja yang hendak melakukan vermak wajah dan tubuh.

Sejak Korean Wave merebak di berbagai negara kunjungan masyarakat manca negara ke sejumlah rumah sakit atau klinik perawatan tubuh di Korea Selatan menjadi meningkat. Tujuan utamanya adalah untuk melakukan operasi plastik. Kesempurnaan fisik yang ditonjolkan melalui produk hiburan Korea Selatan (film, musik, dan drama) telah memengaruhi orang-orang menjadi begitu peduli pada penampilan fisik dan kesempurnaan, baik bagi wanita maupun pria. 
3) Pariwisata:

Setting tempat dan kuliner yang diperlihatkan dalam film, drama, dan video clip juga memberikan pengaruh terhadap kunjungan wisata ke Korea Selatan. Kunjungan dari turis Cina meningkat pada tahun 2005 mencapai 314.433 (11,8 \% dari total kunjungan) dibandingkan dengan tahun 1995 yang hanya 28.909. Sedangkan turis Jepang yang berkunjung ke Korea Selatan juga meningkat yaitu 1.726 orang pada tahun 2003 menjadi 2.354 pada tahun 2004. Turis bukan hanya datang dari dua negara tersebut namun berbagai negara lainnya termasuk Indonesia. Kunjungan wisatawan Indonesia ke Korea Selatan pada tahun 2013 mencapai 30.000 orang. Jumlah tersebut meningkat 30\%-40\% dibandingkan tahun 2012 (liputan6.com).

Salah satu contoh drama yang sukses mendongkrak jumlah kunjungan wisata ke Korea Selatan dan menjadi perintis adalah Winter Sonata. Larisnya drama tersebut pun turut meningkatan pendapatan bisnis hotel, restoran, perdagangan retail dan wholesale mencapai US\$ 6,24 Juta atau 0,1\% dari jumlah Gross Domestic Bruto (GDP) Korea Selatan di tahun 2004 (Eun dan Jiwon, 2007: 122).

\section{4) Studi tentang Korea Selatan:}

Kuliner, bahasa, dan tradisi yang kental dalam produk budaya korea mampu menarik minat masyarakat manca negara. Sejak Korean Wave membahana banyak universitas yang membuka jurusan atau studi tentang Korea Selatan. Hal itu dilakukan karena banyaknya orang yang berminat untuk belajar dan mencari pengetahuan tentang Korea (Cho, 2005).
5) Produk Elektronik (Teknologi):

Salah satu perusahaan Korea Selatan yang naik daun di pasar global adalah Samsung. Samsung merupakan perusahaan chip komputer lokal pertama yang mampu menembus pasar global. Pada saat ini Samsung menjadi perusahaan ponsel terbesar di dunia. Strategy Analytics menyebutkan keuntungan Samsung di kuartal kedua tahun 2013 sebesar US\$5,2 miliar, dan menjadi perusahaan elektronik dengan keuntungan terbesar di dunia. Dari penjualan telepon seluler dunia periode April hingga Juni yang mencapai 386 juta, 27,7\% -nya dikuasai oleh Samsung. Selain Samsung masih ada beberapa perusahaan yang bergerak di bidang transportasi dan produk elektronik yang turut diuntungkan dengan booming Korean Wave ini yaitu Hyundai dan LG.

Dari pemaparan di atas bahwa dapat ditarik benang merah bahwa politik, ekonomi, budaya, dan teknologi yang notabene merupakan ranah subtansi yang berbeda namun pada kenyataanya berjalan secara beriringan/dialektis serupa dengan apa yang digambarkan Kellner. Artinya Korean Wave adalah suatu proses dialektis dari keempat sektor tersebut karena pemunculannya tidak terlepas dari adanya aktor pemerintah yang melegitimasinya dalam suatu tatanan kebijakan dan kemudian mendukung proses masifikasi produk budaya dan teknologi hingga akhirnya memengaruhi sektor ekonomi Korea Selatan seperti saat ini. 


\section{Faktor Meluasnya Korean Wave}

Korean Wave dalam hal ini dianalisis sebagai fenomena globalisasi budaya alternatif yang muncul karena keanekaragaman budaya dunia. Globalisasi bukan hanya dilihat dari persaingan industri komersial secara fisik, sehingga melakukan kegiatan produksi secara ketat. Globalisasi juga bagian dari kontestasi untuk mendapatkan konsumen, memperluas atau meningkatkan jumlah konsumen, dan mempertahankan konsumen dalam kontestasi internasional. Oleh karena itu globalisasi sekarang dibanjiri pula dengan produk budaya ternyata menjadi alat propaganda untuk menarik perhatian dan selera banyak orang.

Wallerstein mengungkapkan tren diferensiasi budaya atau kompleksitas budaya berkaitan dengan sistem kerja ekonomi kapitalis dan budaya sebagai bagian dari ekploitasi (dalam Eun dan Jiwon, 2007: 124). Korea Selatan memang telah menjadi salah satu negara kapitalis Asia selain Singapura, Hongkong, Taiwan, dan sebagainya dengan struktur dan mekanisme berbeda dari kapitalisme Barat (empat naga kecil Asia). Sebagai negara kapitalis, Korea Selatan melakukan strategi untuk mencari keuntungan maksimal dari berbagai komoditas yang bisa dijual. Korean Wave menjadi salah satu strategi yang sukses dalam memperkaya Korea Selatan saat ini sehingga mampu menggeser hegemoni Jepang dan Amerika Serikat. Namun mengkonsep, mewacanakan, dan menyebarkan Korean Wave bukanlah hal yang sederhana. Perlu kejelian dan kreativitas agar Korean Wave bisa diterima dan menarik perhatian banyak orang.
Ada beberapa faktor yang membuat Korean Wave berpengaruh secara luas dan begitu populer di berbagai negara sekaligus menjadi ciri khas Korea Selatan di mata dunia, yaitu sebagai berikut;

a. Mencampurkan nilai tradisional (konfusianisme) dan modernitas.

Korea Selatan menawarkan produk budaya alternatif. Itu dilakukan untuk menghilangkan tendensi terhadap budaya lokal yang sebagian generasi muda dianggap kolot. Nilai-nilai cinta, kekeluargaan dan penghormatan dikolaborasikan dengan konteks modernitas, sehingga produknya menjadi sarana reflektif yang mampu menarik emosi konsumennya. Tema modernitas diambil untuk menarik konsumen muda karena populasi anak muda di dunia terutama Asia lebih besar, dan anak muda akan selalu mudah tertarik dengan produk baru. Tema modernitas lebih banyak difokuskan pada lifestyle (produk IT dan Fashion).

Konfusianisme merupakan tradisi yang bukan hanya dianut oleh Korea Selatan melainkan juga negara tetangga lainya di Asia Timur dan Tenggara. Itulah yang membuat Korean Wave diterima dengan terbuka di negara-negara Asia Timur dan Tenggara, terutama Jepang dan Cina meskipun didera sensitivitas tertentu. Elemen konfusianisme ternyata juga mampu menarik perhatian negaranegara lain yang tidak menganut faham itu. Hal itu karena nilai konfusianisme ternyata juga memiliki nilai universal yang bisa menjadi bahan refleksi para konsumennya.

Nilai konfusianisme tersebut begitu kental dalam produk drama dan film Korea yang selama ini kental dengan nuansa cinta dan kekeluargaan membuat penontonnya larut dalam alur cerita yang penuh 
Jurnal Pemikiran Sosiologi Volume 2 No. 2, 2013

Gelombang Globalisasi ala Korea Selatan

Annissa Valentina, Ratna Istriyani

emosi karena cinta dan keluarga begitu dekat dengan realitas. Tidak seperti produk film Amerika Serikat (Hollywood) yang kental dengan nuansa kekerasan dan persaingan, kemudian Jepang yang terlalu kental dengan animasi atau teknologinya seperti film ultra-man, Godzilla, dan sebagainya.

\section{b. Kreativitas Tinggi}

Peribahasa sekali mendayung dua tiga pulau terlampau cocok untuk menggambarkan usaha Korea Selatan karena begitu total untuk mengkreasikan produknya. Salah satu contohnya produk musik yang sudah menggunakan konsep multibahasa, sehingga tidak hanya memproduksi album dalam bahasa asli melainkan juga album versi Mandarin, Inggris, Jepang, dan sebagainya. Produksi dalam ragam bahasa tersebut merupakan upaya untuk semakin memperluas pangsa pasar karena akan lebih banyak orang yang kemudian bisa menikmati dan memahami lirik dari musik tersebut.

Selain itu adalah produksi film atau drama, tidak hanya sekedar mempromosikan ceritanya saja melainkan juga fashion, musik, teknologi, pariwisata, dan sebagainya yang terekam dalam setiap adegan. Setiap drama atau film yang sukses di pasaran sering diikuti dengan larisnya sountrack album, model baju yang digunakan dalam film/drama, lokasi yang dijadikan tempat syuting juga ramai dikunjungi, dan teknologi seperti handphone atau mobil mengalami peningkatan penjualan. Hal itu yang terjadi pasca pemutaran drama Winter Sonata, Endless Love, Sasy Girl, Secret Garden, dan sebagainya. c. Ramah dan Terbuka

Korean Wave mudah diterima dan menarik perhatian banyak orang karena berusaha menarik kalangan apa pun mulai dari golongan bawah sampai atas dan komunitas dari negara wilayah mana pun. Hal itu dilakukan untuk menghindari kekurangan yang dialami proses Westernisasi dan Japanisasi yang masih terdapat stereotype, diskriminasi, atau sensitivitas terhadap kalangan atau golongan masyarakat tertentu. Misalnya produk Jepang yang kurang begitu diterima di Cina karena sensitivitas masa lalu/sejarah yaitu Jepang pernah menguasai Cina.

d. Kerja sama antara pemerintah dan perusahaan swasta

Kerja sama serta kerja keras antara pemerintah dan perusahaan swasta menjadi faktor penting dalam menyukseskan Korean Wave karena hal adanya peran-peran jelas, saling mendukung, dan konsisten; seperti yang dijelaskan dalam pemaparan di atas. Itulah yang menjadi alasan Korean Wave bukan hanya merupakan kesuksesan bagi industri budaya yang melibatkan media sebagai agen sentral saja melainkan juga menjadi kesuksesan Korea Selatan secara keseluruhan. Program ekspor menjadi orientasi besar yang kemudian mampu diciptakan dalam bentuk kerja sama karena kesadaran bahwa keuntungan bisa semakin maksimal jika dilakukan dalam hubungan gotong-royong yang saling menguntungkan.

Pemerintah Korea Selatan berhasil dalam memberikan modal, akses, dan dukungan kepada industri-industri negaranya. Para pelaku industri Korea Selatan pun juga mampu bekerja sama dan mengelaborasi hasil kreativitasnya. Kegotong- 
Jurnal Pemikiran Sosiologi Volume 2 No. 2, 2013

Gelombang Globalisasi ala Korea Selatan

Annissa Valentina, Ratna Istriyani

royongan tersebut mampu membuat Korea Selatan sukses dalam segala sektor sekaligus mewujudkan impiannya pada masa awal pembangunan yaitu menjadi pemenang dalam kompetisi global, meskipun untuk saat ini masih terlalu dini menyebut Korea Selatan menjadi pemenang.

\section{e. Promosi}

Promosi yang gencar membuat Korean Wave semakin cepat mewabah. Promosi banyak dilakukan melalui media elektronik maupun cetak. Namun media yang paling gencar dan dianggap efektif serta efisien untuk mempromosikan Korean Wave adalah Televisi dan Internet karena media tersebut telah digunakan secara masif dan menjadi jaringan internasional yang mudah diakses. Khususnya internet, banyak media sosial yang menjadi sarana dalam menyerbarkan Korean Wave dan mendekatkan konsumen pada produk tersebut, contohnya Youtube, Twitter, Facebook, Instagram, Skype, dan sebagainya. Bahkan belakangan muncul komunitas/fans club dari berbagai selebritis Korea Selatan dalam skala internasional yang anggotanya mencapai jutaan.

Dengan demikian kontestasi dalam arus globalisasi akan dimenangkan oleh pihak atau negara yang bisa menyebarkan pengaruh politik, budaya, ekonomi, dan teknologi. Kondisi tersebut yang dinikmati Korea Selatan dengan predikat negara maju baru melalui Korean Wave yang dibangun hampir dua dekade. Produk budaya dan teknologi menjadi komoditas yang disebarkan melalui mekanisme ekonomi dan politik yang berjalan secara dialektis.

\section{E. Kesimpulan}

Globalisasi telah memengaruhi pasar dunia, bukan hanya menciptakan hubungan ketergantungan antar negara namun juga kompetisi untuk menjadi negara adikuasa. Selama ini globalisasi selalu diidentikkan dengan Barat dan pengaruhnya terhadap negara-negara di seluruh dunia. Aktor utama yang menjadi fokus globalisasi adalah Amerika. Namun, ada fenomena menarik yang muncul dari negara Asia Timur yang mulai tumbuh dan berusaha menjadi negara sukses dalam persaingan global tersebut, yaitu Korea Selatan. Korea Selatan memang bukan negara Asia pertama yang tumbuh menjadi raksasa dan mulai menguasai pasar global. Sebelumnya, Jepang telah lebih dulu hadir dan merajai pasar Global. Ada yang menarik dari menonjolnya Korea Selatan dalam pasar global, yaitu fenomena Korean Wave atau Hallyu yang tidak terlepas dari suatu proses dialektis politik,ekonomi, budaya, dan teknologi.

Korean Wave menjadi suatu strategi pasar Korea Selatan yang begitu sukses dalam era ini dan mengantarkannya menjadi negara yang mengalami surplus pendapatan karena berbagai produk industrinya yang laris di pasar internasional. Hal itu tidak terlepas dari kreativitas Korea Selatan dalam mengemas produknya dan memanfaatkan globalisasi sebagai ruang menyebarkan produk budayanya. Aktor yang berperan dalam penyebaran Korean Wave ke berbagai negara adalah pemerintah Korea Selatan bekerja sama dengan berbagai perusahaan swasta di negara tersebut.

Program ekspor memang sudah dicanangkan sejak awal tahun 1960-an dengan slogan atau visi penting yaitu memenangkan kompetisi global. 
Jurnal Pemikiran Sosiologi Volume 2 No. 2, 2013

Gelombang Globalisasi ala Korea Selatan

Annissa Valentina, Ratna Istriyani

Korean Wave menjadi misi penting dalam visi

tersebut. Korean Wave tidak terlepas dari kejelian

Korea Selatan dalam membaca pasar, bahwasanya pada era globalisasi seperti sekarang industri bukan sekedar kegiatan produksi secara fisik melainkan juga produksi makna yang kemudian mampu menentukan jumlah konsumsi atas produk tersebut. Kondisi itulah yang kemudian menandai budaya konsumsi atau masyarakat konsumen karena aktivitas konsumsi dikendalikan oleh produsen. Sebagai negara kapitalis, Korea Selatan sukses dalam melakukan ekspansinya yang menarik, efektif, dan efisien.

Hal yang menarik dalam hal ini bukanlah keberhasilan Korea Selatan dalam kontestasi pasar global, melainkan usaha dan prosesnya menjadi negara terdepan dalam pasar global akhir-akhir ini. Satu poin penting dalam hal ini adalah visi dan misi yang terintegrasi secara baik antara pemerintah dan perusahaan-perusahaan yang ada di Korea Selatan dalam bidang politik, ekonomi, budaya dan teknologi. Itulah yang kemudian menjadi ciri khusus kapitalisme Korea Selatan yang cenderung berjalan secara kolektif bukan individualitis. Sekilas strategi yang dilakukan Korea Selatan dengan Korean Wavenya hampir sama dengan Jepang dan Amerika Serikat, namun bedanya Korean Wave menjadi produk alternatif yang mencampurkan unsur Barat dan Timur yang kemudian lebih mudah diterima oleh masyarakat di belahan timur maupun barat. Kesuksesan Korean Wave sebagai strategi ekonomi Korea Selatan secara ringkas dapat dijabarkan dalam lima hal penting yaitu: a. Kedekatan budaya;

b. Sejarah umum dan warisan budaya;

c. Pengalaman tentang peningkatan industri yang pesat pada abad 20 di wilayah Asia Timur;

d. Peningkatan yang pesat dalam perdagangan intraregional, investasi, dan pariwisata;

e. Pengembangan industri teknologi informasi dan industri modern lainnya di Korea Selatan

\section{Daftar Pustaka}

Anonim. 2011. "Fanatisme Remaja Indonesia Pada Korean Wave." Diakses melalui http://shantyfyn.

wordpress.com/2011/11/22/fanatismeremaja-indonesia-pada-korean-wave/.

Diakses pada 17 November 2013 pukul 22.28 WIB.

"Korea, A Creative Country Indeed." Diakses melalui http:// www.investkorea.org/publish/data/ bbs/bulletin/img/06/136IKb_ market.pdf. Diakses pada 22 November 2013 pukul 22.27

.2013. "Samsung Perusahaan Ponsel Terbesar Dunia”. Diakses melalui http://www.bbc.co.uk/ indonesia/ majalah/2013/07/130727_samsung_paling _beruntung.shtml. Diakses pada 23 November 2013 pukul 18.07 WIB.

Baudrillard, Jean. 1998. The Consumer Society: Myth and Structure. London: Sage Publication.

Berger, Peter L. 1990. Revolusi Kapitalis. Terj. Mohamad Oemar. Jakarta: LP3ES 
Deny, Septian. 2013. "Demam K-Pop, Turis RI Berduyun-duyun ke Korea." Diakses melalui http:// bisnis.liputan6.com/read/705771/ demam-k-pop-turis-ri-berduyun-duyun-kekorea. Diakses pada 23 November 2013 pukul 17.16 WIB.

Durham, Meenakshi Gigi dan Douglas M. Kellner (ed). 2006. Media and Cultural Studies. UK: Blackwell Publishing.

Hochschild, Joshua P. 2006. "Globalization: Ancient and Modern." Diakses melalui http:// www.mmisi.org/ir/41_01/ hochschild.pdf pada tanggal 16 November 2013 pukul 12.35 WIB.

Joang, Cho Hae. 2005. "Reading the "Korean Wave" as a Sign of Global Shift." Diakses melalui http://gsis.korea.ac.kr/file/board_data/mb oard/1268123586_1.PDF. Diakses pada 16 November 2013 pukul 12.23 WIB.

Kim, Eun Mee dan Jiwon Ryoo. "South Korean Culture Goes Global: KPop and the Korean Wave" diakses melalui http://kossrec.org/ board/imgfile/KSSJ Vol.34. no.1(Eun Mee Kim\&Jiwon Ryoo)). Pdf. Diakses pada 16 November 2013 pukul 11.50 WIB.

Kushendrawati, Selu Margareta. 2006. "Masyarakat Konsumen Sebagai Ciptaan Kapitalisme Global: Fenomena Budaya Dalam Realitas Sosial." Makara Sosial Humaniora. Vol.10 No 2 edisi Desember. Fakultas Ilmu Budaya Universitas Indonesia.

Nastiti Aulia. "Korean Wave di Indonesia: Budaya Pop, Internet, dan Fanatisme Remaja." Diakses melalui http:// www.scribd.com/doc/67051422/ KoreanWave-di-Indonesia-Budaya-Pop-Internet-
dan-Fanatisme-Remaja pada tanggal 16 November 2013 pukul 17.05 WIB.

Nur, Annisa. 2012. "Pengaruh Budaya Pop Korea Terhadap Eksistensi Kebudayaan Asli Indonesia Di Kalangan Remaja Kota Tegal." Diakses melalui http:// shantyfyn.wordpress. com/2011/11/22/fanatisme-remajaindonesia-pada-korean-wave/. Diakses pada 17 November 2013 pukul 22.24 WIB.

Ritzer George dan Douglas J. Goodman. 2010. Teori Sosiologi. Terjemahan Nurhadi. Yogyakarta: Kreasi Wacana.

Sklair, Leslie. 2002. Globalization, Capitalism, and Its Alternatives (third edition). New York: Oxford University Press.

Subangun, Emmanuel. 1995. Kapitalisme Gotongroyong. Yogyakarta: Cri Alocita. 